\title{
Testing the Impact of the Waste Product from Biogas Plants on Plant Germination and Initial Root Growth
}

\author{
Jana KODYMOVÁ'), Silvie HEVIÁNKOVÁ, Miroslav KYNCL, Jiří RUSÍN
}

\author{
1) Faculty of Mining and Geology, VŠB - Technical University Ostrava, 17. listopadu 15, 70800 Ostrava, Czech Republic; email: \\ jana.kodymova@vsb.cz
}

http://doi.org/10.29227/IM-2021-01-04

Submission date: 08-01-2021 | Review date: 15-05-2021

Abstract
During biogas production, anaerobic digestion of plant material rich in nutrients results in the so-called whole digestate. The appli-
cation of nutrient-rich material present in digestate could have fertilising effects, especially in intensively used agricultural soils, and
in crop yields that can affect the nutrient cycle. The aim of this article is to inform about possibilities of using mixture of digestate and
haylage (use the fertilizing effect of both matters), and at the same time contribute to the improvement of agrochemical properties of
soil. This study evaluates the effect of applying the mixture of digestate and haylage on germination and early stages of plant develop-
ment. This article deals with primary test mixtures of digestate and haylage at ratios 10:1, 5:1 and 3:1 and compares the results with
whole digestate applications. Simplified statistically calculated quantities showed that all examined mixtures better fertilizing effect in
comparison with the control growing media. Based on the chemical analysis of the growing medias, a growing media with mixtures of
digestate and haylage characterizing as growing medias with a high content of nutrients and a low amount of hazardous metal was
investigated. The examined growing media thus met the limits for organic and commercial fertilizers. Fertilizing effects of growing
media with mixture of digestate an haylage can also be noted on increasing the proportion of macronutrients in the soil, reducing
fertilization only throughout whole digestate.

Keywords: digestate, germination, haylage, soil, Petri dishes, biogas station, $\mathrm{pH}$

\section{Introduction}

In the future, humanity will face an increase in the human population leading to more inputs needed to produce food, including arable land, while inorganic minerals and fossil fuels have been on the decline. On the other hand, biogas technology offers a competitive process to manage biodegradable waste streams and to produce renewable energy in a sustainable way. Furthermore, the nutrients present in the waste materials are preserved in the anaerobic digestate, which can be further refined into value-added products, such as organic fertilizers and soil improvers.

Anaerobic digestion is an effective method of biomass processing in biogas plants, in which the organic matter decomposes in the absence of oxygen to give two valuable products, i.e. biogas and digestate. Biogas is a very useful source of renewable energy, while digestate is considered a valuable bio-fertilizer (Yu at al., 2010; Scaliglia at al., 2017). However, Govasmark et al. (2011) and Heviánková et al. (2013) proved the possible occurrence of pathogenic bacteria and heavy metals in digestate. This is why it is important that digestate is safe if used to substitute mineral fertilizers (Vázquez-Rowe et al. 2015)

If digestate is compared with conventional organic fertilizers, i.e. livestock fertilizers, the digestate has a relatively high total nitrogen content from 0.2 to $1 \%$ by weight, higher $\mathrm{pH}$ (78 ), lower carbon and dry matter content ranging from $2-13 \%$. The content of easily degradable organic substances depends on the technical solution of Biogas plant. According to Vítěz et al. (2013), however, the longer the residence time of the BPS substrate, the less readily degradable substances will be present in the resulting digestate.
Many authors have agreed that digestate can be used in agricultural practice as a fertilizer. For example, according to Dimambro (2015), its introduction into agricultural practice can reduce the amount of inorganic fertilizers. According to Stoknes et al. (2016), digestate can serve as the main growing media component for the production of vegetables and mushrooms, and thus significantly improve the commercial profitability of tomatoes, cucumbers and lettuce.

Digestate is often considered as an organic fertilizer, but it contains stable organic matter, so it is rather mineral fertilizer (Heviánková et al., 2014). The use of digestate as fertilizer is limited primarily by hygiene requirements, the presence of hazardous elements and salinity. In a number of fermentation residues, higher concentrations of $\mathrm{Cu}$ and $\mathrm{Zn}$ were found, which did not comply with legislative requirements (Alburquerque et al, 2012). The export of digestate as fertilizer to agricultural land is governed by the Council Directive 91/676/EEC.

Fertilization is one of the main factors generating yield. Used properly, it helps maintain or increase soil fertility and productivity in an environmentally friendly manner. When used incorrectly, especially over a long period of time, it results in adverse changes in soil properties and other agroecosystem components, reduces plant productivity and degrades yield quality (Edmeades 2003, Gamzikov et al. 2007).

A combination of mineral fertilizer and farmyard manure enables to supply plants with nutrients for more than one vegetative growth season. Such fertilization system secures good plant nutrition with mineral nutrients for late growth and development stavage of plants (Bagdoniene, 1997).

The main weakness of digestate, however, is its $\mathrm{pH}$, which is usually ranges from 8.2 to 8.6 , in a wide range of digestates 
Tab. 1. Average germination of samples - Petri dish test

Tab. 1. Średnie kiełkowanie próbek - test na szalce Petriego

\begin{tabular}{|l|c|c|c|c|c|}
\hline AGR (\%) & $\mathbf{1 0 : 1}$ & $\mathbf{5 : 1}$ & $\mathbf{3 : 1}$ & Digestate & Control \\
\hline One dose & 100 & 100 & 97,33 & 100 & 100 \\
\hline $\begin{array}{l}\text { Double } \\
\text { doses }\end{array}$ & 92 & 94.67 & 96 & 96 & 97.33 \\
\hline $\begin{array}{l}\text { Tree times } \\
\text { doses }\end{array}$ & 97.33 & 94.67 & 90.67 & 93.33 & 94.67 \\
\hline $\begin{array}{l}\text { Four times } \\
\text { doses }\end{array}$ & 93.33 & 93.33 & 89.33 & 90.67 & 96 \\
\hline $\begin{array}{l}\text { Five times } \\
\text { doses }\end{array}$ & 96 & 98.67 & 89.33 & 90.67 & 96 \\
\hline $\begin{array}{l}\text { Six times } \\
\text { doses }\end{array}$ & 93 & 94.67 & 90.67 & 97.33 & 96 \\
\hline
\end{tabular}

Tab. 2. Scattering coefficient for average germination - Petri dish test

Tab. 2. Współczynnik rozproszenia dla średniego kiełkowania - test na szalce Petriego

\begin{tabular}{|l|c|c|c|c|c|}
\hline CVG & $\mathbf{1 0 : 1}$ & $\mathbf{5 : 1}$ & $\mathbf{3 : 1}$ & Digestate & Control \\
\hline One dose & 0 & 0 & 4.75 & 0 & 0 \\
\hline $\begin{array}{l}\text { Double } \\
\text { doses }\end{array}$ & 7.53 & 2.44 & 4.17 & 7.22 & 2.37 \\
\hline $\begin{array}{l}\text { Tree times } \\
\text { doses }\end{array}$ & 2.37 & 6.45 & 10.19 & 6.55 & 2.44 \\
\hline $\begin{array}{l}\text { Four times } \\
\text { doses }\end{array}$ & 8.92 & 2.47 & 5.17 & 2.55 & 4.17 \\
\hline $\begin{array}{l}\text { Five times } \\
\text { doses }\end{array}$ & 0 & 2.34 & 5.17 & 6.74 & 4.17 \\
\hline $\begin{array}{l}\text { Six times } \\
\text { doses }\end{array}$ & 2.47 & 2.44 & 17.83 & 4.75 & 4.17 \\
\hline
\end{tabular}

(Heslop and McCabe, 2012; N. Voća et al., 2005; Dimambro, 2012). The optimum $\mathrm{pH}$ range for most soil grown crops is between 5.5 and 7.0, being the range where plant nutrients are most available (Jensen, 2010). The $\mathrm{pH}$ value is most often adjusted with lime, according to a study by Jaskulska et al. (2014), however, it has been shown that this can lead to a deterioration of the agrochemical properties of the soil in the long term.

Therefore, in our study, we tried to adjust the $\mathrm{pH}$ using haylage, which is also organic matter and improves agrochemical conditions in agricultural land.co je cílem článku?

\section{Materials and methods}

Plant material, experimental design and growing conditions

For testing of germination we used Watercress (Lepidium sativum). Watercress is an annual herb growing to a height of $60 \mathrm{~cm}$. Stems at the top of the branches, the leaves are pinnate, the leaves growing at the ground are more pronounced stalked. The flowers are arranged in clusters on the tops of the stems, are white or reddish and only about $2 \mathrm{~mm}$ in size. This plant was selected for testing based on the recommendations of EN 16086-2: 2012-01.

\section{Characteristics of the growing media and nutrient solutions}

We tried to bring our experiment as close as possible to real conditions, but at the same time maintain the methodology given by the EN 16086-2 standard. We used white top peat with a particle size of less than $10 \mathrm{~mm}$, quartz sand in the range of 0.05-0.2 mm and kaolin Sigmaas substrate. The material would be mixed in a weight ratio of 74:20:5. After mixing, the soil was allowed to settle and then its $\mathrm{pH}$ was adjusted to 5.5-6.5, density $90 \mathrm{~kg} \cdot \mathrm{m}^{-3} \pm 20 \%$, and EC $0.1 \mathrm{dS} \cdot \mathrm{m}^{-1}$. the tested digestate came from the family farm Stonava, Czech Republic. The optimal $\mathrm{pH}$ range for most crops grown in soil is between 5.5 and 7.0, which is the range in which plant nutrients are most available (Jensen, 2010). Digestate had 95.67\% water content, and the chemical parameters of the digestate were: TOC (39\%), nitrogen $(\mathrm{N} 7.76 \%)$, phosphorus $\left(\mathrm{P}_{2} \mathrm{O}_{5}\right.$ $10.5 \%)$,potassium $\left(\mathrm{K}_{2} \mathrm{O} 30.2 \%\right)$, and $\mathrm{pH} 7,76$. The haylage was prepared by grinding it into smaller pieces corresponding to a size of $10 \mathrm{~mm}$. At the same time it contained haylage $3223 \%$ water content, and the chemical parameters of the haylage were: TOC (41.7\%), nitrogen $(\mathrm{N} 1.58 \%)$, phosphorus $\left(\mathrm{P}_{2} \mathrm{O}_{5}\right.$ $222 \%)$,potassium $\left(\mathrm{K}_{2} \mathrm{O} 24,2 . \%\right)$, and $\mathrm{pH} 7.76$.

\section{Phytotoxicity test, microbiological analyses and agronomic traits}

To assess the influence of mixtures of digestate and haylage, a phytotoxicity test was performed according to DIN EN 16086-2:2012-01, i.e. by incubating twenty seeds of Lepidium sativum (cress), a high sensitive reference species used in phytotoxicity bioassays according to Wang et al. (2001), at $20^{\circ} \mathrm{C}$ in Petri dishes, replicated tree times.

We prepared growing media in Petri dishes by adding digestate and haylage under conditions of 10:1 (3.15 g of digestate and $0.35 \mathrm{~g}$ of haylage), 5:1 (2.92 $\mathrm{g}$ of digestate and $0.58 \mathrm{~g}$ of haylage) and 3:1 (2.62 g digestate and $0.88 \mathrm{~g}$ of haylage) and whole digestate (3.5 g of digestate), three Petri dishes were used as controls. The sealed foil-sealed Petri dishes are incubated for 72 hours at an angle of $70^{\circ}$ to $80^{\circ}$ to the horizontal, with the seeds sown at the top and the growing media at the bottom, in the dark at a constant value of $25 \pm 5^{\circ} \mathrm{C}$.

Seventy two hours after germination, the germination index percentage (GI\%) was calculated according to the formula GI\% $=100 \times(\mathrm{G} 1 / \mathrm{G} 2) \times(\mathrm{R} 1 / \mathrm{R} 2)$, where G1 and G2 are germinated seeds in the sample and control, and R1 and R2 are mean root lengths for the sample and for the control, respectively.

The concentration of mixures matters (digestate and haylage) was then increased by adding a given proportion of digestate and hay again to the same Petri dishes, and new watercress seeds were reseeded after 4 hours. The fifth replicates of these increasing concentration were performed in this way.

\section{Flame AAS analysis and GC analysis}

These analyses were performed on flame atomic absorption spectrometry (AAS) using Mehlich-3 extraction (Mehlich, 
Tab. 3. Root length index - Petri dish test

Tab. 3. Wskaźnik długości korzenia - test na szalce Petriego

\begin{tabular}{|l|c|c|c|c|c|}
\hline RI (\%) & $\mathbf{1 0 : 1}$ & $\mathbf{5 : 1}$ & $\mathbf{3 : 1}$ & Digestate & Control \\
\hline One dose & 104.27 & 119.03 & 110.30 & 111.97 & 100 \\
\hline $\begin{array}{l}\text { Double } \\
\text { doses }\end{array}$ & 118.23 & 125.48 & 120.92 & 128.76 & 100 \\
\hline $\begin{array}{l}\text { Tree times } \\
\text { doses }\end{array}$ & 142.17 & 126.37 & 120.29 & 126.74 & 100 \\
\hline $\begin{array}{l}\text { Four times } \\
\text { doses }\end{array}$ & 139.18 & 129.54 & 117.53 & 133.66 & 100 \\
\hline $\begin{array}{l}\text { Five times } \\
\text { doses }\end{array}$ & 137.63 & 159.94 & 128.35 & 131.49 & 100 \\
\hline $\begin{array}{l}\text { Six times } \\
\text { doses }\end{array}$ & 144.15 & 134.04 & 131.26 & 131.45 & 100 \\
\hline
\end{tabular}

Tab. 4. Munoo-Liis vitality index - Petri dish test

Tab. 4. Wskaźnik witalności Munoo-Liisa - test na szalce Petriego

\begin{tabular}{|l|c|c|c|c|c|}
\hline MLV (\%) & $\mathbf{1 0 : 1}$ & $\mathbf{5 : 1}$ & $\mathbf{3 : 1}$ & Digestate & Control \\
\hline One dose & 104.27 & 119.03 & 107.32 & 111.97 & 100 \\
\hline $\begin{array}{l}\text { Double } \\
\text { doses }\end{array}$ & 112.03 & 122.03 & 119.62 & 127.53 & 100 \\
\hline $\begin{array}{l}\text { Tree times } \\
\text { doses }\end{array}$ & $\mathbf{1 4 6 . 1 6}$ & 126.68 & 115.30 & 124.97 & 100 \\
\hline $\begin{array}{l}\text { Four times } \\
\text { doses }\end{array}$ & 136.29 & 126.13 & 109.77 & 126.36 & 100 \\
\hline $\begin{array}{l}\text { Five times } \\
\text { doses }\end{array}$ & 137.63 & $\mathbf{1 6 4 . 5 1}$ & 119.98 & 124.66 & 100 \\
\hline $\begin{array}{l}\text { Six times } \\
\text { doses }\end{array}$ & 140.37 & 132.30 & $\mathbf{1 2 8 . 1 4}$ & $\mathbf{1 3 3 . 0 7}$ & 100 \\
\hline
\end{tabular}

1984; Wolf and Beegle, 1994). The suitability of the extraction solution Mehlich 3 for determination of fertiliser requirement was tested using the correlations between the contents of the corresponding plant nutrients in the parallel soil-plant samples. According to Sen Tran \& Simards (1993), the extraction solution according to the Mehlich 3 method consists of : $0.2 \mathrm{~N} \mathrm{CH}$ ${ }_{3} \mathrm{COOH}, 0.25 \mathrm{~N} \mathrm{NH}_{4} \mathrm{NO}_{3}, 0.013 \mathrm{~N} \mathrm{HNO}_{3}, 0.015 \mathrm{~N} \mathrm{NH}_{4} \mathrm{~F}$ and $0.001 \mathrm{M}$ EDTA - combines microelements into complex compounds and avoids precipitation of $\mathrm{Ca}$. Phosphorus, potassium, magnesium, copper and manganese were determined from the plant material by dry ashing of office analytical method: $\mathrm{K}$ 71/250 EEC; Mg, Mn - 78/633 EEC.

For determination of nutrients in soil (phosphorus, ammonia nitrogen - N-NH${ }^{4+}$, nitrite nitrogen - $\mathrm{NO}^{3}$ ) by GC analysis was carried out with a gas chromatograph equipped with a flame photometric detector (P-filter) with using Mehlich-3 extraction (Mehlich, 1984; Wolf and Beegle, 1994). Macronutrients in soil $(\mathrm{Ca}, \mathrm{Mg}, \mathrm{K}, \mathrm{Na}$ ) were determined using Gilligam solution (Gillman, 1976).

All chemical analyses were made at a Czech accredited laboratory.

\section{Statistical analysis}

Experimental data were analysed using software Statistica for factorial analysis of variance (ANOVA). Multivariate data analysis was performed using principal component analysis (PCA) to assess the existing relationships between the variables examined and the parameters recorded.

\section{Results and discussion}

Today, soilless cultivation systems use large amounts of non-renewable materials (Ronga et al., 2016); Therefore, alternative growing medias are needed to improve the sustainability of production. Digestate (mainly solid digestate) appears to be suitable as a growing media (Stoknes et al., 2016), although, as some reports on compost suggest, high $\mathrm{pH}$ promotes their mixing with other matrices capable of reducing this value (Bugbee, 1996; Ronga et al., 2016).
The results of the measured root lengths and the calculated percentage of germination from the number of germinated seeds, from tests on Petri dishes, were further used in the calculations of statistical quantities determined by the standard EN 16086-2: 2011. Interestingly, no effects of phytotoxicity on Watercress were observed in this study (Table 1): all mixtures, including digestate, gave germination index values above $50 \%$, which is commonly recognized as a threshold value for many crops (Zucconi et al., 1981).

In particular, all doses of mixtures and digestate gave a very similar germination value as the control samples (their difference compared to the germination of the control sample ranged from 5-7\%), the most significant improvement in germination was achieved with a triple dose of digestate and haylage in a ratio of 10: 1 . Similar results were obtained by Gell et al. (2011) and Sánchez et al. (2008), who evaluated digestive phytotoxicity on lettuce, radish, wheat and watercress.

Responses in terms of germination of seeds of Lepidium sativum can be used to evaluate toxic effects on plants, thus allowing the determination of the quality of waste through a simple assay (Zucconi et al., 1985). The toxic effects on plants are a combination of multiple factors (Zucconi et al., 1981).

Table 2 contains data on the coefficient of variation for the root length. It is valid that the larger the coefficient, the more the data differ from the average (the difference is again determined on the basis of the squares and its difference between the arithmetic average and the measured value). Here, too, it can be seen that the coefficients are relatively low, so in most tests we worked with a homogeneous set, which showed a relatively low variability of measured values.

In the case of determining the root length index according to EN 16086-2: 2012-01, the control sample is taken as the default value, which is assigned a value of $100 \%$, for other mixtures it is then calculated and determined whether their lengths are greater (or shorter) than the root in the control sample. In general, we could say that the rule is that the longer the root, the better the fertilizing effect of the mixture. In our 
Tab. 5. Germination indices of watercress phytotoxicity test

Tab. 5. Wskaźniki kiełkowania testu fitotoksyczności rukwi wodnej

\begin{tabular}{|l|l|l|l|l|l|}
\hline & $10: 1$ & $5: 1$ & $3: 1$ & Digestate & Control \\
\hline IV $(\mathrm{mm})$ & 5.02 & 4.59 & 3.81 & 4.58 & 4.59 \\
\hline kv $(\%)$ & 79.2 & 79.2 & 72 & 73.8 & 72 \\
\hline IK $(\%)$ & $\mathbf{1 2 0 . 3 9}$ & $\mathbf{1 1 0 . 0 0}$ & $\mathbf{8 3 . 0 5}$ & $\mathbf{1 0 2 . 2 5}$ & $\mathbf{1 0 0 . 0 0}$ \\
\hline
\end{tabular}

Tab. 6. Average elemental composition of the soil after the experiment

Tab. 6. Przeciętny skład pierwiastkowy gleby po doświadczeniu

\begin{tabular}{|l|l|l|l|l|l|l|}
\hline & units & $10: 1$ & $5: 1$ & $3: 1$ & Digestate & Control \\
\hline $\mathrm{pH}$ & & 6.7 & 6.6 & 6.6 & 7.1 & 6.8 \\
\hline $\begin{array}{l}\text { Calcium } \\
(\mathrm{Ca})\end{array}$ & $\begin{array}{l}\mathrm{mg} / \mathrm{kg} \text { of dry } \\
\mathrm{matter}\end{array}$ & 300 & 284 & 268 & 336 & 256 \\
\hline $\begin{array}{l}\text { Magnesium } \\
(\mathrm{Mg})\end{array}$ & $\begin{array}{l}\mathrm{mg} / \mathrm{kg} \text { of dry } \\
\mathrm{matter}\end{array}$ & 38 & 36 & 36 & 33 & 31 \\
\hline $\begin{array}{l}\text { Potassium } \\
\text { (K) }\end{array}$ & $\begin{array}{l}\mathrm{mg} / \mathrm{kg} \text { of dry } \\
\mathrm{matter}\end{array}$ & 37 & 41 & 49 & 31 & 18 \\
\hline $\begin{array}{l}\text { Sodium } \\
\text { (Na) }\end{array}$ & $\begin{array}{l}\mathrm{mg} / \mathrm{kg} \text { of dry } \\
\mathrm{matter}\end{array}$ & 18 & 20 & 18 & 19 & 16 \\
\hline $\begin{array}{l}\text { Exchange } \\
\text { acidity } \\
(\mathrm{Al+H})\end{array}$ & $\begin{array}{l}\mathrm{mmolchekv/} \\
\mathrm{kg}\end{array}$ & $<1$ & $<1$ & $<1$ & $<1$ & $<1$ \\
\hline $\begin{array}{l}\text { Ammonia } \\
\text { nitrogen }\end{array}$ & $\mathrm{mg} / \mathrm{kg}$ & 1440 & 1410 & 1520 & 1280 & 1560 \\
\hline $\begin{array}{l}\text { Total } \\
\text { nitrogen }\end{array}$ & $\begin{array}{l}\% \text { of dry } \\
\mathrm{matter}\end{array}$ & 0.15 & 0.17 & 0.18 & 0.14 & 0.16 \\
\hline $\begin{array}{l}\text { Total } \\
\text { organic } \\
\text { carbon }\end{array}$ & $\begin{array}{l}\% \text { of dry } \\
\mathrm{matter}\end{array}$ & 3.51 & 3.35 & 3.6 & 2.77 & 2.64 \\
\hline
\end{tabular}

monitored samples, the root length index was above $100 \%$ for all examined samples (see Table 3).

In addition to the average root lengths, the Munoo-Liis vitality index (Table 4) also takes germination into account. Here, too, all the samples examined were above $100 \%$. It again confirms that all the mixtures examined can be used as fertilizer. All mixtures showed increased germination compared to the control sample. In the case of digestate, we reached the same values as in the study of Maunuksel et al. (2012), which, in addition to pot tests with Chinese cabbage (Brassica pekinensis) and barrels, also performed germinating ten cress seeds (Lepidium sativum). No similar studies were found to compare other mixtures.

According to Table 5 of results of the germination index of tested samples from the watercress phytotoxicity test, samples 3: 1 , digestate and haylage can be interpreted as well-mature "compost" and samples 10:1, 5:1 and digestate as compost with stimulating ability. All tested samples came out above $80 \%$, which means that the fertilizing effect decreases and the effect of humus is stronger, i.e. that nutrients are more bound. Nitrogen and phosphate release is slower and nutrients do not leach into groundwater. All examined samples are therefore satisfactory from the point of view of the determined phytotoxicity on watercress germination.

The best ratio of germination indices was 10:1 with the resulting germination index of $120.39 \%$. Another ratio is divided by a ratio of 5:1 with a separate with a germination index of $110 \%$. Another digestion index, which was above $100 \%$, was a digestate sample.

These results confirmed a study performed by Dimambr (2015), which showed that appropriately diluted digestate (in terms of $\mathrm{NH}_{4}-\mathrm{N}$ concentrations, $\mathrm{pH}$ and electrical conductivity) can generally achieve similar or higher yields compared to standard growing methods.

The most important indicators in the table are probably $\mathrm{pH}$ and ammoniacal nitrogen. When the $\mathrm{pH}$ rises above 6.5 some of the nutrients, micro-nutrients begin to precipitate out of the solution and can no longer be absorbed by the crop (Rush, 1987).

Hence for some horticultural crops reducing the $\mathrm{pH}$ below 7 is recommended, such as for hydroponic tomato (Neal and Wilkie, 2014), cucumber (Liedl, 2006) and lettuce production (Liedl, 2004b). At the same time a number of studies have highlighted the importance of considering the quantity of mineral $\mathrm{N}$ in digestates as this is the portion of $\mathrm{N}$ which is readily available to the crop (WRAP, 2012; Risberg, 2015). For horticultural purposes, a number of authors have highlighted the importance of matching the NH4-N concentration of the digestate to the crop requirements (Neal and Wilkie, 2014; Liedl, 2004a).

From this point of view, the values in the case of digestate appear to be the least suitable. As in the study according to Calamai (2020), all mixtures showed a significant increase in the content of secondary macronutrients $(\mathrm{Ca}, \mathrm{Na}, \mathrm{K}, \mathrm{Mg})$. The degree of alkaline saturation is an important indicator of agricultural soil quality. The value of this characteristic below $50 \%$ indicates a degraded soil (fertilisation, crop rotation), at the level of 50-75\%, also agrotechnical errors, only values above $85 \%$ indicate a good physicochemical condition of the soil. As emphasised by Brodowski et al. (2005) and Cheng et al. (2006), this parameter plays a crucial role in the retention of water and nutrients for plants. Cation exchange capacity is important for maintaining adequate quantities of plant-available $\mathrm{Ca}, \mathrm{Mg}$, and $\mathrm{K}$ in soils. The applied fertilisation also influenced the share of cations in the sorption complex, generally decreasing the share of $\mathrm{H}+$ ions and increasing slightly the share of $\mathrm{Ca}^{2+}$ ions and more clearly increasing the share of $\mathrm{Mg}^{2+}$ and $\mathrm{K}^{+}$cations. The optimal Ca to $\mathrm{Mg}$ ratio should be 7:1 (Eabetowicz, 1999). According to Sanik et al. (1952), the $\mathrm{Ca}: \mathrm{Mg}$ ratio has an impact on the solubility of cations in the soil solution. In our study, the ratio in the case of mixtures was in the range of 7.8-7.4:1, in contrast, in the case of diges- 
tate, the range was 10.1:1. The test results for the digestate are the same as for the research by Glowack et al. (2020).

\section{Conclusion}

In all cases of the examined samples of the determined test with watercress on Petri dishes, the growth of the root length was stimulated in comparison with the control growing media. From all statistically calculated quantities it can be deduced that all tested growing medias are in a positive position compared to the control growing media. Growing medias therefore have a positive effect on plant development. Based on chemical analyses of growing medias performed in the accredited laboratory Morava, the mixed growing medias can be characterized as growing medias with high nutrient content and heavy metal content meeting the limits for organic and livestock fertilizers according to EU regulation 2019/1009., On setting requirements for fertilizers, as amended. From the results of the watercress phytotoxicity test according to Plíva et al. (2006), it can again be deduced that the researched mixture matters are growing medias with fertilizing effects and can be used as fertilizer in all aspects. Due to the low homogeneity of the investigated growing medias, the results were not objectively comparable, and therefore it is not possible to say unambiguously which mixture of the tested ratios was the most suitable for root growth and germination. However, all mixtures achieved a more significant improvement in the agrochemical properties of the soil compared to whole digestate fertilization. For a clear conclusion, it would be necessary to continue testing in a longer time horizon and in real conditions, such as in the case of a long-term experiment in Jaskulska et al. (2014) or Glowack (2020), who examined the impact of different agricultural practices on soil quality and yields.

\section{Acknowledgments}

This paper was supported by the Ministry of Agriculture of the Czech Republic within the Project QJ1320159 "Research of treatment, utilization and disposal of waste products from biogas station" and also was supported from ERDF "Institute of Environmental Technology - Excellent Research" (No. CZ .02.1.01/0.0/0.0/16_019/0000853). Experimental results were accomplished by using Large Research Infrastructure ENREGAT supported by the Ministry of Education, Youth and Sports of the Czech Republic under project No. LM2018098.

\section{Literatura - References}

1. Alburquerque, J. A., et al. (2012) Assessment of the fertiliser potential of digestates from farm and agroindustrial residues. Biomass and Bioenergy, vol. 40, pp 181-189.

2. B. Scaglia, M. Pognani, F. Adani. (2017) The anaerobic digestion process capability to produce biostimulant: the case study of the dissolved organic matter (DOM) vs. auxin-like property, Science of the Total Environment, 589, pp. 36-45.

3. Bagdoniene, V. (1997) Plant yield, its quality and agrochemical charakters in the crop rotation on the soil of heavy granulometric composion in biological and chemialised agriculture. Argiculture Scientfic Articels, 58, pp. 38-46.

4. Brodowski, S.; Amelung, W.; Haumaier, L.; Abetz, Z.; Zech, W. (2005) Morphological and chemical properties of black carbon in physical soil fractions as revealed by scanning electron microscopy and energy dispersive $\mathrm{x}$-ray spectroscopy. Geoderma,128, 116.

5. Bugbee G.J. (1996) Growth of Rhododendron, Rudbeckia, and Thujia and the leaching of nitrates as affected by the $\mathrm{pH}$ of potting media amended with biosolids compost, Compost Science and Utilization, 4, pp. 53-59.

6. Calamai, A ; Chiaramonti, D; Casini, D; Masoni, A; Palchetti, E (2020) Short-Term Effects of Organic Amendments on Soil Properties and Maize (Zea maize L.) Growth (2020) AGRICULTURE-BASEL, 10, Issue 5, Article Number158.

7. Cheng, C.H.; Lehmann, J.; Thies, J.E.; Burton, S.D.; Engelhard, M.H. (2006) Oxidation of black carbon by biotic and abiotic processes. Org. Geochem., 37, 477.

8. Dimambro M.E. (2015) Novel uses for digestates: protected horticulture 20th European Biosolids \& Organic Resources Conference \& Exhibition. Available at https://www.researchgate.net/profile/Mary_Dimambro/publication/284169259_Novel_uses_for_digestate_Protected_horticulture/links/573b29c208ae9ace840e9fa1.pdf

9. Dimambro M.E. (2015) Novel uses for digestates: protected horticulture. 20th European Biosolids \& Organic Resources Conference \& Exhibition. Available at https://www.researchgate.net/profile/Mary_Dimambro/publication/284169259_Novel_uses_for_digestate_Protected_horticulture/links/573b29c208ae9ace840e9fa1.pdf

10. Edmeades D.C. (2003) The long-term effects of manures and fertilisers on soil productivity and quality: A review. Nutrient Cycling in Agroecosystems, 66: 165-180.

11. EN 16086-2:2012-01 Soil improvers and growing media - Determination of plant response - Part 2: Petri dish test using cress. 
12. Gamzikov G.P., Barsukov P.A., Varvain O.D. (2007) Change in agrochemical properties of sod-podzolic soil during long-term fertilization. Russian Agricultural Sciences, 33: 314-317.

13. Gell K. , van Groenigen J.W. , Cayuela M.L. (2011) Residues of bioenergy production chains as soil amendments: immediate and temporal phytotoxicity, Journal of Hazardous Materials, 186, pp. 2017-2025.

14. Glowacka, A; Szostak, B; Klebaniuk, R. (2020) Effect of Biogas Digestate and Mineral Fertilisation on the Soil Properties and Yield and Nutritional Value of Switchgrass Forage, AGRONOMY-BASEL, 10, Issue: 4, Article Number: 490.

15. Govasmark E., Stäb J., Holen B., Hoornstra D., Nesbakk T. (2011) Chemical and microbiological hazards associated with recycling of anaerobic digested residue intended for agricultural use. Waste Management 31, 2577 - 2583.

16. Heslop, V. \& McCabe, T. (2012). Demonstration of compost and digestate use in Irish agriculture, Years 1 and 2.

17. Heviánková S., Kyncl M., Langarová S. (2013) Investigating the current management of digestate in the Czech Republic. Journal of the Polish Mineral Engineering Society, July - December, 119 - 124.

18. Heviánková, S., Kyncl, M., Kodymova, J. (2014) Study and research on cleaning procedures of anaerobic digestion products. GeoScience Engineering, vol. LX, no. 2, pp. 47-58.

19. HortScience, poster abstract, 41, 997. Risberg, K. (2015). Quality and function of anaerobic digestion residues. PhD, Swedish University of Agricultural Sciences, Uppsala.

20. Jaskulska I., Jaskulski D., Kobierski M. (2014) Effect of liming on the change of some agrochemical soil properties in a long-term fertilization experiment. Plant Soil Environ., 60: 146-150.

21. Jensen, T. L. (2010). Soil pH and the Availability of Plant Nutrients. IPNI Plant Nutrition TODAY, 2.

22. Labetowicz, J.M.; Kuszelewski, L.; Korc, M.; Szulc, W. (1999) The importance of organic fertilisation for crop stability and ionic balance of light soil. Zesz. Prob. Post. Nauk Rol., 465, 123-1334.

23. Liedl, B. E., Cummins, M., Young, A., Williams, M. L., Chatfield, J. M. (2004a). Liquid effluent from poultry waste bioremediation as a potential nutrient source for hydroponic tomato production. Acta Horticulturae, 659, 647-652.

24. Liedl, B. E., Cummins, M., Young, A., Williams, M. L., Chatfield, J. M. (2004b). Hydroponic lettuce production using liquid effluent from poultry waste bioremediation as a nutrient source. Acta Horticulturae, 659, 721-728.

25. Liedl, B. E., Wilfong, K., Taylor, C., Mazzaferro, K. (2006). Liquid effluent from poultry waste bioremediation as a nutrient source for hydroponic cucumber production.

26. Marada, P., Vačeřová V., Kamarád L., Dundálková P. , Mareček J (2008) Manual for handling digestate and fugate. [online]. 2edition. Mendel University of Agriculture and Forestry.

27. Maunuksela, Liisa \& Herranen, Mirkka \& Torniainen, Merja. (2012). Quality Assessment of Biogas Plant End Products by Plant Bioassays. International Journal of Environmental Science and Development. 3. 305-310.

28. Mehlich A. (1984). Mehlich 3 soil test extraction: a modification of Mehlich 2 extractant, Communications in Soil Science and Plant Analysis, 15, pp. 1409-1416.

29. Neal, J. \& Wilkie, A. C. (2014). Anaerobic Digester Effluent as Fertilizer for Hydroponically Grown Tomatoes. University of Florida Journal of Undergraduate Research, 15, 1-5.

30. Oleszczuk, P. (2008) Phytotoxicity of municipal sewage sludge composts related to physico-chemical properties, PAHs and heavy metals, Ecotoxicol. Environ. Saf., vol. 69, pp. 496-505.

31. Plíva, P. et al. (2006) Establishment, course and management of the composting process. Praha: Research Institute of Agricultural Technology. ISBN 80-86884-11-2.

32. REGULATION (EU) 2019/1009 OF THE EUROPEAN PARLIAMENT AND OF THE COUNCIL of 5 June 2019 laying down rules on the making available on the market of EU fertilising products and amending Regulations (EC) No 1069/2009 and (EC) No 1107/2009 and repealing Regulation (EC) No 2003/2003.

33. Ronga D. , Pane C. , Zaccardelli M. , Pecchioni N. (2016) Use of spent soffee ground compost in peat-based growing media for the production of basil and tomato potting plants, Communications in Soil Science and Plant Analysis, 47, pp. 356-368.

34. Sanik, J., Jr.; Perhins, A.T.; Schrenk, W.G. (1952) The effect of the calcium -magnesium ratio on the solubility and availability of plant nutrients. Soil Sci. Soc. Am. Proc.,16, 263-267.

35. Stoknes K., Scholwin F., Krzesiński W., Wojciechowska E., Jasińska A. (2016) Efficiency of a novel "Food to waste to food" system including anaerobic digestion of food waste and cultivation of vegetables on digestate in a bubble-insulated greenhouse, Waste Management, 56, pp. 466-476. 
36. Vítěz T., Geršl M., Mareček J., Kudělka J., Krčálová E. (2013) Mineralogical-chemical characteristics of fermentation residues in laboratory biogases and possibilities of their use for evaluation of soil properties. Mendel University in Brno and the Ministry of Agriculture of the Czech Republic. Available at: http://eagri.cz/public/web/file/325087/ MZE_fermentacni_zbytek_final_2013.pdf

37. Voća N., Ćosić T., Rupić V., Jukić Ž., Kalambura S. (2005). Digested residue as a fertilizer after the mesophilic process of anaerobic digestion. Plant, Soil, Environment, 51, 262- 266.

38. Wang X. , Sun C. , Gao S. , Wang L. , Shuokui (2001) Validation of germination rate and root elongation as indicator to assess phytotoxicity in Cucumis sativus, Chemosphere, 44, pp. 1711-1721.

39. WRAP (2012). Digestate \& compost in agriculture. Bulletin 3 - March 2012. Field experiments focus on crop available nitrogen supply from digestate. Banbury: WRAP.

40. Yu F.B. , Luo X.P. , Song C.F., Shan S.D. (2010) Concentrated biogas slurry enhanced soil fertility and tomato quality, Acta Agriculturae Scandinavica Section B-Soil and Plant Science, 60, pp. 262-268.

41. Zucconi F. , Pera A. , Forte M., Bertoldi M. De (1981) Evaluating toxicity of immature compost, BioCycle, 22, pp. 54-57.

\section{Badanie wplywu produktów odpadowych z biogazowni na kiełkowanie roślin \\ i początkowy wzrost korzeni}

Podczas produkcji biogazu fermentacja beztlenowa bogatego w składniki pokarmowe materiału roślinnego skutkuje powstaniem tzw. pofermentu. Zastosowanie materiału bogatego w składniki odżywcze obecnego w pofermencie może mieć działanie nawozowe, zwłaszcza dla intensywnie użytkowanych gleb rolniczych oraz dla plonów, może wpływać na cykl składników odżywczych.

Celem artykułu jest przedstawienie możliwości wykorzystania mieszanki pofermentu i sianokiszonki (wykorzystanie efektu nawozowego obu substancji), a jednocześnie przyczynienie się do poprawy właściwości agrochemicznych gleby.

W pracy oceniono wpływ zastosowania mieszanki pofermentu i sianokiszonki na kiełkowanie i wczesne etapy rozwoju roślin. Artykuł dotyczy podstawowych mieszanek testowych pofermentu i sianokiszonki w proporcjach 10:1, 5:1 i 3:1 i porównuje wyniki z zastosowaniem całego pofermentu. Uproszczone statystycznie obliczone ilości wykazały, że wszystkie badane mieszanki mają lepsze działanie nawozowe w porównaniu z kontrolnymi podłożami uprawowymi. Na podstawie analizy chemicznej podłoży uprawowych zbadano podłoża uprawowe z mieszanina pofermentu i sianokiszonki, charakteryzujące się jako podłoża uprawowe o wysokiej zawartości składników odżywczych i niskiej zawartości metali niebezpiecznych. Badane podłoża uprawowe spetniały tym samym limity dla nawozów organicznych i komercyjnych. Nawozowe efekty podłoży uprawowych mieszanka pofermentu i sianokiszonki można również zauważyć na zwiększenie udziału makroskładników w glebie, ograniczając nawożenie tylko w samym pofermencie.

Słowa kluczowe: poferment, kiełkowanie, sianokiszonka, gleba, szalki Petriego, stacja biogazowa, odczyn pH 